\title{
Cardiac devices in the pediatric population: an overview of the indications and complications
}

\section{Dispositivos cardíacos en la población pediátrica: una visión general de las indicaciones y complicaciones}

\author{
Juan Simon Rico-Mesa ${ }^{1,2}$, William Sovic ${ }^{1}$, Pranav Penninti ${ }^{1}$
}

\begin{abstract}
Pacemakers, implantable cardioverter-defibrillators, and biventricular pacemakers have similar uses in the pediatric population as they do in the adult population. Pacemaker indications are similar in adults and children: sinus node dysfunction and second or third degree atrioventricular blocks. Pacemaker candidacy in pediatrics, however, must take into account the patient's symptom burden rather than absolute heart rate cutoffs. Normal ranges for heart rates in children are also different than adults and vary depending on a child's age. The guidelines for implantable cardioverterdefibrillators likewise are similar to those for adults, being indicated as secondary prevention for sudden cardiac death survivors and as primary prevention in select patients who experience ventricular tachycardia. However, there are currently no specific recommendations for these devices in children with congenital heart defects. Likewise, though there is new promising research, there are currently no specific indications for biventricular pacing in children. The potential complications of pediatric cardiac devices relate to the different heart rate requirements children have compared to adults and the general procedural risks associated with cardiac implants (infection, bleeding, device failure). Despite the recent growth in the use of cardiac devices in children, there is still much room for continued research into the potential indications for and complications from these tools in the pediatric population. Unfortunately, the lack of evidence holds true not only for South America but worldwide. Research studies conducted in South America would give a better understanding about the demographic differences in terms of outcomes.
\end{abstract}

Keywords: pacemaker, implantable cardioverter-defibrillator, biventricular pacemakers, cardiac resynchronization therapy, pediatrics

\section{RESUMEN}

El uso de dispositivos cardiacos incluido el marcapasos, desfibrilador cardiaco implantable y el marcapasos biventricular (resincronizador cardiaco) tienen usos similares en la población pediátrica al igual que en población adulta. En niños, el marcapasos está indicado en su mayoría en casos de disfunción del nodo sinusal y en bloqueos atrioventriculares de segundo y tercer grado. La candidatura para el uso de marcapasos pediátrico debe tener en cuenta la cantidad de síntomas del paciente por encima de los límites predeterminados de frecuencia cardiaca. Los rangos normales de frecuencia cardiaca en población pediátrica difieren de las metas en población adulta y varían acorde a la edad del paciente. Las guías sobre el uso de desfibrilador cardiaco implantable son similares a las de adultos, haciendo énfasis en el uso de dispositivos principalmente en prevención secundaria de muerte súbita cardiaca y en prevención primaria en selectos pacientes pediátricos con alto riesgo de arritmias ventriculares. Sin embargo, a la fecha no existen recomendaciones específicas para el uso de estos dispositivos en cardiopatías congénitas. Así mismo, aunque existen en curso numerosas investigaciones para el uso de marcapasos biventriculares, aún no existen guías de tratamiento claras para su implementación. El potencial de complicaciones en dispositivos cardiacos implantables, entre ellas infección, sangrado y falla de dispositivos han sido comparadas con la prevalencia en población adulta. A pesar del reciente auge en el uso de dispositivos cardiacos en niños, existe aún gran cabida para futuras investigaciones en cuanto a las indicaciones de implantación y las complicaciones asociadas. Desafortunadamente, la carencia de evidencia aplica tanto para Suramérica como para el resto del mundo. Futuros estudios realizados en Suramérica facilitarían el entendimiento dada la mejoría en la información a nivel local.

Palabras clave: marcapasos, desfibrilador cardioversor implantable, marcapasos biventricular, terapia de resincronización cardíaca, pediatría

\footnotetext{
1 Department of Medicine, University of Texas Health San Antonio, San Antonio, Texas, United States

2 Department of Cardiovascular Diseases, Division of Echocardiography, Mayo Clinic, Rochester, Minnesota, United States

Correspondence: Juan Simon Rico-Mesa

Department of Medicine, University of Texas Health San Antonio, San Antonio, Texas, United States

Department of Cardiovascular Diseases, Division of Echocardiography, Mayo Clinic, Rochester, Minnesota, United States

Received: 6 Sep 2018, Accepted: 14 Apr 2019

E-mail:juansimonrico@hotmail.com
}

(C) 2019 by the authors; licensee Modestum Ltd., UK. This article is an open access article distributed under the terms and conditions of the Creative Commons Attribution License (http://creativecommons.org/licenses/by/4.0/).

Electronic Journal of General Medicine 


\section{BACKGROUND}

Over the second half of the $20^{\text {th }}$ century, pacemakers were increasingly used in the pediatric population. And while in the first decade of the $21^{\text {st }}$ century the number of pacemakers implanted in children each year stabilized, there has been a recent growth in the use of implantable cardioverter-defibrillators (ICD) and biventricular pacemakers in children for the treatment of cardiac diseases (1). This article will examine the indications and potential complications of these different cardiac devices in the pediatric population.

\section{PACEMAKERS IN THE PEDIATRIC POPULATION}

The three most common general indications for pacemaker implantation in pediatrics are symptomatic sinus bradycardia, tachycardia-bradycardia syndrome, and second or third degree atrioventricular (AV) block due to both congenital and post-surgical etiologies (2). The American College of Cardiology Foundation/American Heart Association Task Force on Practice Guidelines and the Heart Rhythm Society 2012 describes specific Class I, Class Ila, and Class IIb recommendations for the use of permanent pacemakers in the pediatric population. These recommendations take into account factors of cardiac disease that are unique to children. Many pediatric patients who are suitable candidates for pacing have a history of congenital heart defects or congenital corrective surgeries. These patients have abnormal cardiac physiology that can result in symptoms at lower heart rates than individuals with normal physiology. Therefore, compared to the adult population, the degree of symptoms with which a possible pacemaker candidate patient presents as opposed to the degree of bradycardia is more important in determining pacemaker candidacy in pediatrics. The definition of bradycardia itself in children is also different than that of adults. The cutoff for bradycardia exists along a continuum in pediatrics, decreasing as children age (3). This too must be taken into consideration when determining pacemaker candidacy in pediatrics (2).

A unique need for cardiac devices exists in Latin America because of the Trypanosoma cruzi parasite endemic to South America. Chagas disease, an illness caused by infection with the parasite, can result in significant cardiac disease, notably dilated cardiomyopathies and AV nodal heart blocks. Chagas accounts for $25-30 \%$ of pacemaker implants in Brazil (and around $26 \%$ of ICD implants in data aggregated from seven different Latin American countries) (4). And though the overall use of pacemakers in the general population for the treatment of Chagas related heart blocks in Brazil has remained the same, pediatric pacemaker use for Chagas disease has decreased, perhaps due to better control of transmission of the parasite (5).

\section{IMPLANTABLE CARDIOVERTER-DEFIBRILLATORS IN THE PEDIATRIC POPULATION}

Although fewer than $1 \%$ of all ICDs are implanted in children (6), their use in the pediatric population is particularly important because, compared to adults, children who are hospitalized and undergo resuscitation for sudden cardiac death (SCD) are much less likely to survive (7). The overall lifetime risk of an episode of SCD in a patient with risk factors since childhood makes ICDs a valuable treatment modality for kids.

As in adults, the 2012 ACCF/AHA/HRS guidelines for cardiac device therapy and the 2015 European Society of Cardiology Guidelines for the prevention of sudden cardiac death recommend ICD placement in children who have survived cardiac arrest and in those with sustained ventricular tachycardia associated with congenital heart disease, with a class I recommendation. These recommendations are derived primarily from randomized clinical trials performed on adults $(2,8)$. Similar to guidelines in the adult population, ICD is a reasonable treatment option for children with hypertrophic cardiomyopathy and with high-risk channelopathies like Long-QT Syndrome. These diseases also represent a higher proportion of causes of sudden cardiac death in younger patients than in older patients (9).

Other than as above, there are not yet specific guidelines for the recommendation of ICD placement in patients with congenital heart defects despite an increased risk of SCD in these patients. SCD represents the most common cause of death after tetralogy of Fallot repair (10). There is also a greater risk of SCD in patients after repair of transposition of the great vessels or congenital aortic stenosis compared to the general population (11). One recent study looked at different factors in patients with tetralogy of Fallot repair in order to determine which patients would most benefit from ICD placement. Khairy et al. (2008) found that higher left ventricular end-diastolic pressure (hazard ratio of 1.3 per 1 $\mathrm{mmHg}$ increase, $P=0.004$ ) and non-sustained ventricular tachycardia (hazard ratio of $3.7, P=0.023$ ) both independently predicted appropriate ICD shocks in patients with tetralogy of Fallot repairs (12). 
Table 1: Complications of pediatric cardiac device implantation, aggregate data from 1997, 2000, 2003, and 2006 US Kids' Inpatient Database

\begin{tabular}{lcc}
\hline & Pacemaker & BCD \\
\hline Device-related complications (e.g. issues with a generator, lead, or electrode) & $7.2 \%$ & $11.5 \%$ \\
\hline Patient-related complications (e.g. pneumothorax, hematoma, infection) & $11.2 \%$ & \\
\hline Total complications & $17.3 \%$ & $19.9 \%$ \\
\hline
\end{tabular}

ICD = Implantable cardioverter-defibrillator; $\mathbf{B i V}=$ Biventricular pacemaker.

Source: Adapted from Czosek et al. (2012) (1).

\section{BIVENTRICULAR PACEMAKERS}

In 1997 and 2000, no occurrences of biventricular device (BiV) implantation in children were recorded in the US Health Department Kids' Inpatient Database. In 2003 and 2006, there were a combined 82 instances of BiV implantation in children recorded (1). However there are still currently no guidelines for the implantation of BiV in children. The guidelines that exist for adults generally apply to pathologies that are uncommon in children or not readily extrapolated to the pediatric population, such as reduced left ventricle ejection fraction (LVEF) $<35 \%$, NYHA functional class II/III, and variable QRS prolongation, usually more than $140 \mathrm{mmHg}(2)$. However, a 2005 retrospective study of 103 pediatric patients, 73\% with congenital heart disease, $16 \%$ with cardiomyopathy, and 13\% with complete heart block, who underwent BiV implantation showed an overall improvement in systemic ventricle ejection fraction by $12.8 \pm 12.7 \%$ (ejection fraction was measured before and after implantation by echocardiography in 74 patients and by radionuclide scan in 14 patients). There was no significant difference in ejection fraction improvement among the different heart disease groups (congenital heart disease, cardiomyopathy, and complete heart block). Several patients in the study were ultimately removed from cardiac transplant waiting lists, suggesting that BiV therapy could be possibly used to prevent or delay end-stage heart failure $(13,14)$.

\section{COMPLICATIONS}

Given that children have higher heart rates at rest and during exercise than adults, pediatric pacemakers must also track and pace at higher rates. Traditional limits to the maximum tracking rate found in adult pacemakers can result in worsened cardiorespiratory capacity during exercise in children. Ideally pacemakers capable of higher maximum tracking rates (up to 170 to 190 beats per minute) should be utilized in the pediatric population (15).

Pacemakers and ICDs can be implanted in epicardial and transvenous fashions. The latter can also be implanted subcutaneously. Epicardial pacing is generally required in patients with inadequate body size (patients less than 10-15 $\mathrm{kg}$ ) and prohibitive heart anatomy (intracardiac shunts, post Fontan hearts, and prosthetic tricuspid valves). Otherwise transvenous pacing is generally preferred. Transvenous pacing is less invasive as it avoids thoracotomy, allows for lower pacing thresholds (and therefore a longer battery life), and has a lower incidence of lead fractures and failure (16-18). However, the more serious possible complications associated with either transvenous pacemakers and ICDs include endocarditis/infection, venous occlusion, perforation, and embolism (19).

According to the Kids' Inpatient Database, from 1997 to 2006 the most common complications from cardiac device implantation were hematoma (3.3\%), surgical infection (2.4\%), pneumothorax (2.2\%), death (1.7\%), and endocarditis/pericarditis (1.1\%). During the same time-frame, BiV implantations in children were associated with the highest percentage of acute procedural complications at $42.3 \%$, while pacemaker and ICD were similar at $17.3 \%$ and $16.8 \%$ respectively. BiV procedural complications were higher than both pacemaker and ICD for device-related complications (occurring in $26.7 \%$ of BiV procedures) and patient-related complications $(19.4 \%$ of procedures) $(1,19)$. A summarized table is shown in Table 1.

\section{CONCLUSION}

The use of cardiac devices in children, particularly ICD and BiV, is a growing field in contemporary pediatric medicine. The ACCF/AHA Task Force on Practice Guidelines recognizes the need for further research to determine the role of ICDs for primary prevention of SCD in children with channelopathies, cardiomyopathies, and congenital heart defects. Likewise, the Task Force acknowledges that there is a need for research into the efficacy of BiV in pediatric populations with dilated cardiomyopathy and congenital heart disease (2); there is evidence that BiV implantation could possibly avert or stall end-stage heart disease in certain cases of these diseases. Though there is significant evidence on the risks 
and complications of cardiac devices in the adult population, further research is needed to better understand the effects of these devices on the pediatric population.

\section{Conflicts of interest}

The authors declare that there is no conflict of interest.

\section{REFERENCES}

1. Czosek RJ, Meganathan K, Anderson JB, Knilans TK, Marino BS, Heaton PC. Cardiac rhythm devices in the pediatric population: utilization and complications. Heart Rhythm. 2012;9(2):199-208. https://doi.org/10.1016/j.hrthm.2011.09.004 PMid:21907171

2. Tracy CM, Epstein AE, Darbar D, et al. 2012 ACCF/AHA/HRS focused update of the 2008 guidelines for devicebased therapy of cardiac rhythm abnormalities. J Am Coll Cardiol. 2012;60(14):1297-313. https://doi.org/10.1016/j.jacc.2012.07.009 PMid:22975230

3. Fleming $\mathrm{S}$, Thompson $\mathrm{M}$, Stevens $\mathrm{R}$, et al. Normal ranges of heart rate and respiratory rate in children from birth to 18 years of age: a systematic review of observational studies. The Lancet. 2011;377(9770):1011-8. https://doi.org/10.1016/S0140-6736(10)62226-X

4. Dubner $\mathrm{S}$, Valero $\mathrm{E}$, Pesce $\mathrm{R}$, et al. A Latin American registry of implantable cardioverter defibrillators: the ICDLABOR study. Ann Noninvasive Electrocardiol. 2005;10(4):420-8. https://doi.org/10.1111/j.1542474X.2005.00060.x PMid:16255752

5. Mizzaci CC, Souza TGSE, Targueta GP, Tótora APF, Mateos JCP, Mateos JCP. Pacemaker implants in children and adolescents with Chagas disease in Brazil: 18-year incidence. Arq Bras Cardiol. 2017;108(6):546-51. https://doi.org/10.5935/abc.20170074 PMid:28699977 PMCid:PMC5489325

6. Kozak L, Owings MF, Hall MJ. National Hospital Discharge Survey: 2002 annual summary with detailed diagnosis and procedure data. Vital Health Stat 13. $2005 ;(158): 1-199$.

7. Eisenberg $M$, Bergner $L$, Hallstrom A. Epidemiology of cardiac arrest and resuscitation in children. Ann Emerg Med. 1983;12(11):672-4. https://doi.org/10.1016/S0196-0644(83)80413-2

8. 2015 ESC Guidelines for the management of patients with ventricular arrhythmias and the prevention of sudden cardiac death: the task force for the management of patients with ventricular arrhythmias and the prevention of sudden cardiac death of the European Society of Cardiology (ESC) endorsed by: Association for European Paediatric and Congenital Cardiology (AEPC). Europace. 2015;euv319. https://doi.org/10.1093/europace/euv319 PMid:26318695

9. Adabag AS, Luepker RV, Roger VL, Gersh BJ. Sudden cardiac death: epidemiology and risk factors. Nat Rev Cardiol. 2010;7(4):216-25. https://doi.org/10.1038/nrcardio.2010.3 PMid:20142817 PMCid:PMC5014372

10. Nollert GD, Däbritz SH, Schmoeckel M, Vicol C, Reichart B. Risk factors for sudden death after repair of tetralogy of Fallot. Ann Thorac Surg. 2003;76(6):1901-5. https://doi.org/10.1016/S0003-4975(03)01065-8

11. Silka MJ, Hardy BG, Menashe VD, Morris CD. A population-based prospective evaluation of risk of sudden cardiac death after operation for common congenital heart defects. J Am Coll Cardiol. 1998;32(1):245-51. https://doi.org/10.1016/S0735-1097(98)00187-9

12. Khairy P, Harris L, Landzberg MJ, et al. Implantable cardioverter-defibrillators in tetralogy of Fallot. Circulation. 2008;117(3):363-70. https://doi.org/10.1161/CIRCULATIONAHA.107.726372 PMid:18172030

13. Dubin AM, Janousek J, Rhee $\mathrm{E}$, et al. Resynchronization therapy in pediatric and congenital heart disease patients: an international multicenter study. J Am Coll Cardiol. 2005;46(12):2277-83. https://doi.org/10.1016/j.jacc.2005.05.096 PMid:16360058

14. Singh HR, Batra AS, Balaji S. Cardiac pacing and defibrillation in children and young adults. Indian Pacing Electrophysiol J. 2013;13(1):4-13. https://doi.org/10.1016/S0972-6292(16)30584-8

15. Mathony $\mathrm{U}$, Schmidt $\mathrm{H}$, Gröger $\mathrm{C}$, et al. Optimal maximum tracking rate of dual-chamber pacemakers required by children and young adults for a maximal cardiorespiratory performance. Pacing Clin Electrophysiol PACE. 2005;28(5):378-83. https://doi.org/10.1111/j.1540-8159.2005.09330.x PMid:15869668

16. Fortescue EB, Berul Cl, Cecchin F, Walsh EP, Triedman JK, Alexander ME. Patient, procedural, and hardware factors associated with pacemaker lead failures in pediatrics and congenital heart disease. Heart Rhythm. 2004;1(2):1509. https://doi.org/10.1016/j.hrthm.2004.02.020 PMid:15851146 
17. Singh HR, Batra AS, Balaji S. Pacing in children. Ann Pediatr Cardiol. 2013;6(1):46-51. https://doi.org/10.4103/0974-2069.107234 PMid:23626436 PMCid:PMC3634247

18. Sachweh JS, Vazquez-Jimenez JF, SchoÈndube FA, et al. Twenty years experience with pediatric pacing: epicardial and transvenous stimulationq. Thorac Surg. 2018;7.

19. Phibbs B, Marriott HJL. Complications of permanent transvenous pacing. N Engl J Med. 1985;312(22):1428-32. https://doi.org/10.1056/NEJM198505303122205 PMid:3887169

\section{$\diamond \diamond \diamond \diamond \diamond \diamond \diamond$}

http://www.ejgm.co.uk 